\title{
Moving from faith-based concerns to demarginalising youths through the Circle of Courage
}

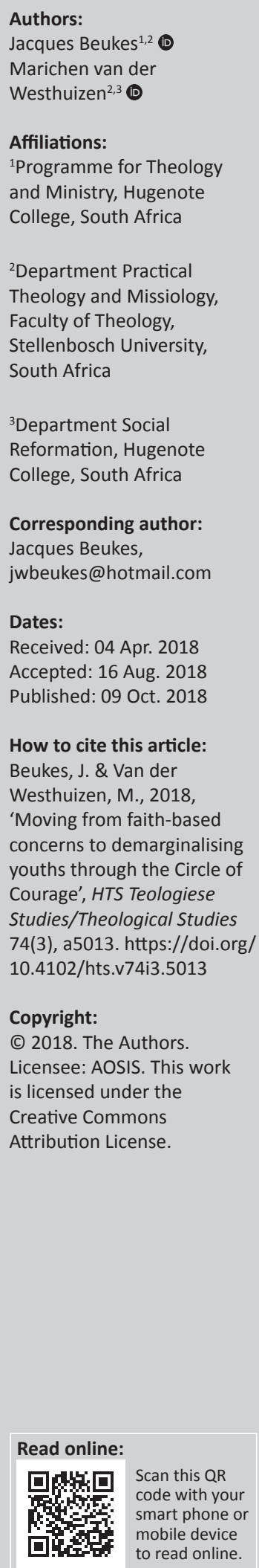

\begin{abstract}
Although the demarginalisation of youths is an international concern, South African youths are viewed by various scholars and policy documents as a particularly vulnerable and marginalised group. It becomes essential to understand what characterises their marginalisation in order to find innovative ways to work towards their demarginalisation. In this article we reflect on current faith-based concerns and compare this with the specific characteristics of the marginalisation of young people. In an effort to contribute to the development of a strategy towards demarginalisation, we will explore the key features of the Circle of Courage in terms of the principles of belonging, mastery, independence and generosity. We will further propose the inclusion of Ubuntu principles in the practical application of the Circle of Courage for churches and faith-based organisations in demarginalising youth in the South African context.
\end{abstract}

\section{Introduction}

As in the rest of the world (cf. Columbia Global Policy Initiative 2014:6), South African youths are viewed as a vulnerable and marginalised group within present-day society (Department of Social Development 2013:30). Of a variety of contributing factors, the three main factors identified are poverty, unemployment and exclusion. This view is supported by various research findings and statistics related to young people being excluded from education, employment and/or training opportunities (Department of Higher Education and Training 2017). Other social issues that marginalise South African youths are reported to include a high drop-out rate in educational settings, inadequate skills development, inadequate youth work services, poor health, high HIV and AIDS prevalence, high rates of substance abuse, crime and violence, a lack of access to sporting and cultural development opportunities, a lack of social cohesion and volunteerism, and disability and exclusion (Republic of South Africa 2015:10-15). Recognising these marginalising factors and emphasising the need to demarginalise youth, the National Youth Policy (Republic of South Africa 2015:3) acknowledges youth as a key resource for social development with the potential to act as 'key agents for social change, economic expansion and innovation'.

Churches and other faith-based organisations (FBOs) ${ }^{1}$ are acknowledged by Van der Westhuizen and Swart (2015:748-752) as key role-players in addressing social issues that marginalise youth. These authors also accentuate that the voices of the marginalised youth should direct practice (praxis) and that services should lead to the empowerment of people. This means that because social issues can marginalise young people, their specific concerns should address the way we assist them to become demarginalised. Based on this viewpoint, we argue that in order to demarginalise young people, we need to understand what characterises their marginalisation.

In this article, we will firstly look at current concerns of churches and other FBOs as faith-based concerns regarding the marginalisation of youths. Secondly, we will explore this marginalisation in terms of statistical descriptions and research that reflect the current situation of young people in South African. Thirdly, we will look at the key features of the Circle of Courage that relate to both marginalisation and demarginalisation (Brendtro, Brokenleg \& Von Brockern 2002). The Circle of Courage is a model of positive youth development and is based on the principles of belonging, mastery, independence and generosity to enhance young people's interests, skills and abilities. The Circle gives us an idea of 'what to focus on' in order to create spaces and opportunities for youths to become demarginalised (Inter-Agency Network for Education in Emergencies [INEE] 2016). We will use this model to recommend how it can be used as a practical method

\footnotetext{
Although churches and congregations could also be described as FBOs, for the sake of this article we will refer to churches and other FBOs. The reason for this is that FBOs are more often than not NGOs. However there is also a degree of complexity attached to the FBOs. The reason for this is that FBOs are more often than not NGOs. However, there is also a degree of complexity attached to the
signifier of ' $F B O$ ', as it is often broadly used to refer to a broad range of faith-based actors that includes faith-based representative organisations, faith-based charitable or development organisations, faith-based socio-political organisations, faith-based missionary organisations and even faith-based illegal or terrorist organisations. In this case study, FBOs will refer to faith-based development organisations (cf. Bowers du Toit 2017:2; Clarke 2006:840).
} 
through which faith-based efforts can move towards actively practicing the Ubuntu principles (Nagel 2008:11-16), which are arguably non-existent in the current socio-economical context.

\section{Faith-based concerns related to youths}

The role of churches and other FBOs in supporting and caring for vulnerable groups such as the youth is, amongst others, also to alleviate suffering, to empower them with knowledge and skills related to healthy living (including spiritual health) and to practice caring for others (Flint, Atkinson \& Kearns 2002:7). Supporting this line of thought, Cloete (2015:1) claims that the youth should be included in the community of faith as a primary space for faith formation. Moreover, she argues that the youth is in need of relationships, and congregations or other FBOs should provide relationships that contribute to their spiritual growth through belonging to a serving community. Furthermore, including the youth in the theology of the church is needed to ensure that they are able to overcome challenges, referring to the mastery of skills to empower them to address aspects that influence healthy living effectively. Therefore, this inclusion should also equip youths to become active members of the church and society, referring to becoming independent and generous individuals (cf. Republic of South Africa 2015:10-15).

Although Nel (2001:21) describes the congregation as an 'agogical'2 (changing) space where young people are accepted for whom they are and for who they are becoming, in reality this is not always the experience of the youth (cf. Beukes \& Van der Westhuizen 2016:24-25). In a similar tone, Knoetze (2015:1) asserts that the active inclusion of young people remains a challenge for both FBOs and congregations and argues that although the largest part of the African population consists of children and youths, the church in Africa still needs to identify a contextual framework for children and youth ministries to ensure effective services to them. In this article, we propose that the African Ubuntu principles be revisited to ensure that ministries function in a context-related manner. These ministries and services should lead to a sense of well-being that supports efforts of demarginalisation. In agreement with the mentioned viewpoints, Cloete (2012:70) states that youth ministry could help to place the focus on real-life issues and experiences of young people. Therefore, youth ministries, as well as FBO services to them, should focus not only on cognitive processes of knowing or behavioural changes but also on creating spaces where they can discover themselves in the face of God. This argument places the need to support young people with a sense of belonging (to the church community), mastery (leading to a feeling of worthiness), independence (supporting dignity) and generosity (becoming active citizens). In support of working with the youth in terms of present needs with a long-term aim to support them to

2.Firet $(1977,1986)$ refers to the term 'agogic' moments when indicating moments of change (cf. Calitz 2017; Cloete 2015; Nel 2009). Knoetze (2017) also uses the term 'agogic' when describing the church as an ever-changing community. become contributors to society, Cloete (2015:4) suggests a paradigm shift from the understanding that the youth should only be acknowledged because of their possible value for tomorrow, towards the understanding that they are valued members of the faith community 'now' and could make a valuable contribution today.

Also focusing on assisting young people with their felt and developmental needs, the National Youth Policy (Republic of South Africa 2015:25-26) refers to FBOs as a valuable potential contributor to the empowerment of youth. Demarginalisation, according to this document, should focus on a holistic development; including emotional, social, cognitive, physical and spiritual aspects, such as opportunities to:

- Achieve potential.

- Learn about and practice honesty and work ethics.

- Perform acts of kindness.

- Take initiative for their own development.

- Show love, respect and care to themselves and others, in particular the elderly, orphans, people with disabilities and other vulnerable groups such as women and children.

- Say no to racism, sexism, xenophobia and other related intolerances.

- Act as guardians of community peace by participating in efforts to curb violence and criminality in their communities (Republic of South Africa 2015:25-26).

Knoetze (2015:3) refers to the dire circumstances in which children and young people in an African context are living and asks: 'What does God expect from his church when 37000 children die of preventable or poverty-related diseases each day?' He (Knoetze) then proceeds by arguing that there is a lack of understanding of the importance of this ministry and that it should be 'transformational; the church must aim for Christian discernment to recognise and understand what God is doing at the moment with those who are being ministered to'. Therefore, faith-based concerns acknowledge the importance of the role of churches and other FBOs, whilst also highlighting that these concerns can only be addressed through including the youth's realities and voiced concerns. In order to become able to focus on the above-mentioned opportunities, we firstly explore the extent of the marginalisation of South African young people, together with a description of their own understanding of their challenges and concerns.

\section{Marginalised youths}

The topic of marginalised youth is an international concern. An international conference hosted by the Columbia Global Policy Initiative (2014:6) was specifically aimed at addressing this topic. It was noted by the participants at this conference that young people are globally 'particularly vulnerable to economic shocks, social instability and conflicts and they are frequently left behind despite widespread development in other age groups'. The Organisation for Economic Co-operation and Development asserts that 'one in ten youth are "left behind" in that they are no longer in school and 
experience various challenges to their development' (as quoted by Furlong et al. 2014:17). Fagan et al. (2014:9) add that, although youth rights are widely emphasised, they are rarely found at decision-making tables where they are viewed as active and respected citizens. This aspect is explained in terms of the view that young people are still developing into adults and that this transition period limits their ability to contribute to efforts of demarginalisation. Additionally, young people are often stereotyped within their societies as rowdy, rebellious and unreliable. Interesting enough, this has been true over the centuries. Socrates, the classical Greek philosopher described adolescents as children who 'contradict their parents, do not respect their elders, are indolent, eat gluttonously and tyrannise their teachers' (Louw \& Louw 2007:281-282). This viewpoint results in judgements that could lead to marginalisation. For example, youth are not being viewed and valued for who they are now, and therefore marginalised as a part of civil society (Cloete 2015:4; Laiq et al. 2014:11-12). The National Youth Policy (Republic of South Africa 2015:26), in an effort to empower youth (i.e. demarginalise them), places the emphasis on the fact that support given to youths should be based on what they need to become active citizens.

Within the South African context, Statistics South Africa (2015:7) found that young men and women face increasing uncertainty and disillusionment in their hopes of undergoing a satisfactory entry to the labour market and that this uncertainty and disillusionment can, in turn, have damaging effects on individuals, communities, economies and society at large (cf. Columbia Global Policy Initiative 2014:6). With regards to employment, employers are often not willing to risk taking on young and inexperienced employees and further prejudice and discrimination is experienced for youth coming from disadvantaged backgrounds (Kousiakis 2015:2). Yet, youths are at a stage of their life where they can become operational as agents of change (Republic of South Africa 2015:25). They have the power to bring new ideas with fresh insight and will be the future leaders of the societies they live in. In the current bleak landscape for marginalised youth attempting to find work, it is not just about securing employment, it is also about hope for a better future.

It should also be noted that unemployed youths are less able to contribute effectively to national development and have fewer opportunities to exercise their rights as citizens. They have less to spend as consumers, less to invest as savers and often have no 'voice' to bring about change in their lives and communities (Statistics South Africa 2015:3). This aforementioned description of the lack of influence of youth unemployment is particularly alarming, considering that South Africa is listed together with Greece and Spain as the three countries with the highest unemployment rate amongst youth in the world (Kousiakis 2015:1; World Economic Forum 2014:14). Socio-economic inequality and inadequate education are mentioned as two factors that drive such high unemployment rates. In order to highlight how contexts that influence the well-being of youth differ, Table 1 indicates the unemployment rate amongst the youth by province during 2015 .

Table 1 highlights the trends over the period 2008-2015. It is evident that the youth unemployment rate increased by the largest amount in the Northern Cape (by 11.3 percentage points) and North West (by 8.8 percentage points). Amongst adults, the increases were smaller, at 8.4 percentage points in Northern Cape and 4.5 percentage points in North West. Limpopo stands out as the province in which the unemployment rate was amongst the lowest for youths and adults. It was also the only province in which the rate declined (by 13.2 percentage points amongst youth and by 7.0 percentage points amongst adults) over the period 20082015. Although this outcome has to be viewed in the context of a shift into discouragement amongst all age groups who gave up hope of finding employment and exited the labour force altogether, it also confirms the higher unemployment rate amongst the youth in South Africa.

The interplay between unemployment and poverty is acknowledged by Statistics South Africa (2017a:29) and it is noted that children between 0 and 17 years are affected the most as $51 \%$ of these children live below the breadline, followed by $43.6 \%$ of youths between the ages of 19 and 24 years. Additionally, the exceedingly high number of young people who are not in employment, education or training (NEET) is of grave concern, both nationally as well as internationally. Figure 1 shows the South African NEET rate by age group from 2013 to 2016 . The youths aged $25-34$ years recorded the highest NEET rate when compared with the other age groups. In 2016, the NEET rate for this group was

TABLE 1: Unemployment rate by province.

\begin{tabular}{|c|c|c|c|c|c|c|}
\hline \multirow[t]{2}{*}{ Province } & \multicolumn{3}{|c|}{ Amongst Youth(15-34 Years) } & \multicolumn{3}{|c|}{ Amongst Adults(35-64 Years) } \\
\hline & 2008 & 2015 & Difference & 2008 & 2015 & Difference \\
\hline Western Cape & 25.9 & 29.9 & +4.0 & 9.3 & 13.6 & +4.3 \\
\hline Eastern Cape & 37.6 & 41.0 & +3.4 & 16.6 & 18.3 & +1.7 \\
\hline Northern Cape & 33.8 & 45.1 & +11.3 & 13.9 & 22.3 & +8.4 \\
\hline Free State & 34.9 & 39.4 & +4.5 & 13.9 & 21.3 & +7.3 \\
\hline KwaZulu-Natal & 30.5 & 33.4 & +2.8 & 12.8 & 13.8 & +1.0 \\
\hline North West & 30.9 & 39.7 & +8.8 & 13.2 & 17.7 & +4.5 \\
\hline Gauteng & 32.4 & 39.8 & +7.3 & 13.3 & 19.5 & +6.2 \\
\hline Mpumalanga & 32.9 & 38.8 & +5.9 & 13.6 & 17.5 & +3.9 \\
\hline Limpopo & 43.5 & 30.4 & -13.2 & 18.0 & 11.0 & -7.0 \\
\hline
\end{tabular}

Source: Statistics South Africa, 2015, National and provincial labour market: Youth, StatsSA, Pretoria 


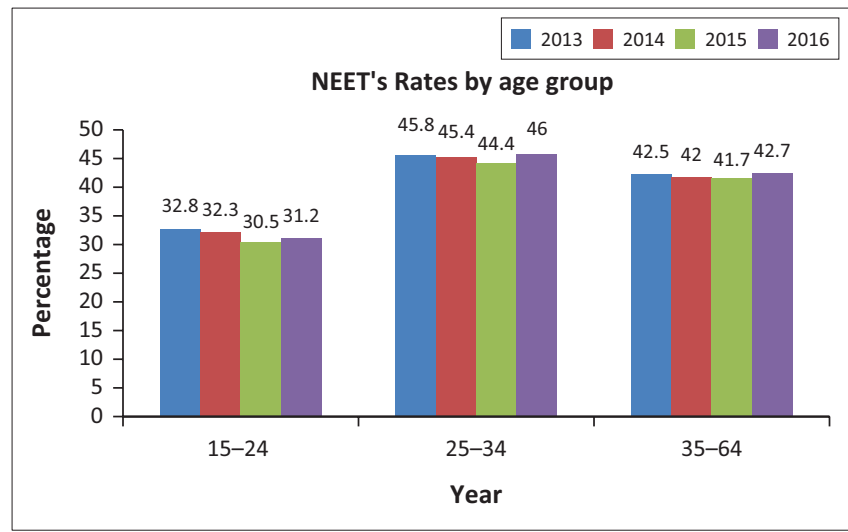

Source: Department of Higher Education and Training, 2017, Fact Sheet on 'NEETS' (Person who are Not in Employment, Education or Training) viewed 15 March 2017, from http:// www.dhet.gov.za/Planning\%20Monitoring\%20and\%20Evaluation\%20Coordination/Factsheet-on-NEETs-Final-Version-27-Jan-2017.pdf

FIGURE 1: Not in employment, education or training rates by age group, from 2013 to 2016. NEET, not in employment, education or training.

$46.0 \%$, followed by the adults aged 35-64 years with $42.7 \%$ and the youth aged $15-24$ years with $31.2 \%$. The NEET rates for the youths aged 15-24 years reported a declining trend from 2013 until 2015 and then increased slightly in 2016. Although the NEET rates for adults aged 25-34 years and 35-64 years reflected a declining trend from 2013 until 2015, the highest NEET rates were recorded in 2016 (Department of Higher Education and Training 2017:4; Statistics South Africa 2017b:11).

The statistical description highlights how, in a country such as South Africa, an increasing gap between rich and poor, education challenges, social unrest, poverty and youth unemployment pose a threat to social and economic stability and development (National Planning Commission 2012:26). Subsequently, unemployed youths are being categorised as marginalised youths as unemployment tends to bring with it a multitude of social problems including poverty, crime, gangsterism, drug and alcohol abuse, poor health, exclusion, loss of self-esteem and confidence (Rankin, Roberts \& Schöer 2012:5). A significant number of young people have become discouraged in their search for work. Particularly for youths living in disadvantaged settings, unemployment and lack of opportunity can lead to life-long experiences of marginalisation. An alarming comment by Rankin et al. (2012:5) is that long-term unemployment together with the associated poverty and social issues also contribute to an even bleaker potential to move out of poverty and become demarginalised when youth remain unemployed for longer than 3 years. This constrains citizens' access to opportunities to positively affect their lives and lift themselves out of poverty (Kousiakis 2015:2).

Furlong et al. (2014:17-18) confirm the above long-term effect of youth unemployment and relate this to social and emotional 'scarring effects'. Furthermore, youth in South Africa from low-income communities are vulnerable to high levels of daily stressors, which are said to increase the risk of negative developmental outcomes (Mosavel et al. 2013:245-255). On a similar note, Pieterse (2015:876-879) are also of the opinion that the exposure to domestic violence, single-headed households, malnutrition, alcohol and drug abuse and maltreatment are all major factors influencing the lives of youths. Warnick (2017:156-157) explored the influence of childhood exposure to domestic violence on young adults and found that it has a significant influence on their emotional and social well-being. The participants in this study reported that they felt and continued to feel unloved and unwanted, that they lacked positive role models, that it caused them to leave school at an early age and that they still continued to live unstable lives (cf. Stanley, Miller \& Foster 2012:192-201). This had a long-term negative influence on their sense of self, thus further marginalising them (cf. Thornton 2014:90-100). These findings highlight the need to include children in efforts to demarginalise youth. Also emphasising the relevance of including children when attempting to demarginalise youths, we argue that both children and youths, as vulnerable and marginalised groups should be supported and prepared to become active citizens through faith-based services (Beukes \& Van der Westhuizen 2016:124-125). However, this support should be based on an acknowledgement of the previously mentioned social challenges (Republic of South Africa 2015:10-15).

In a further effort to understand how youths experience their needs and challenges, we reflected on a study that focused on children and youth's expressed needs regarding their place as members of a faith community (cf. Beukes \& Van der Westhuizen 2016:24-27). The findings supported the description of marginalised youths above in terms of poverty, unemployment, a lack of family harmony and structure and a feeling of not being important. The participating children and youths highlighted a need to develop spiritually and to be engaged in Biblical teachings by means of creative, interactive and stimulating activities. They explained that current practices were not aimed at their level and that they found it to be boring and irrelevant to their realities. Additionally, they asserted that active children and youth groups within congregations should provide them with opportunities to develop social, leadership and management skills. Becoming active participants in broader society was also a need described by the participants. The findings in the mentioned study were contextual in nature, but we argue that these findings capture aspects that marginalise youth experience in general (cf. Department of Higher Education and Training 2017:4; Kousiakis 2015:1; Rankin et al. 2012:5; Statistics South Africa 2017b:11; World Economic Forum 2014:14) and that this, amongst others, can inform a strategy to move towards the demarginalisation of youths. Furthermore, we argue that the empowerment of youths starts during childhood and that the needs of children should not be ignored.

Flint et al. (2002:7) describe the principles of services by the church and refer to, amongst others, empowering members (in this case children and youths) to deal with challenges (i.e. mastery), to assist them to develop a sense of purpose 
(i.e. independence), to develop collective values and norms (i.e. belonging and generosity) and to provide them with a space where trust, safety and a feeling of belonging could be experienced. The youth in the study by Beukes and Van der Westhuizen (2016:24-27) explained the importance of socialising with their peers as a mode of belonging. Children and youth ministries have the potential to provide young people with an opportunity to socialise with other Christian peers and to develop a sense of belonging where they experience support and acceptance. This experience can contribute to betterment needs that are being addressed according to Hertnon's theory of universal human needs. Children and youth ministries can thus contribute to this aspect, as children and youths are encouraged to participate in a Christian community where interactions are based on respect for others, valuating life and opportunities and doing good deeds for others. The aim is to integrate these values in identity formation and the development of a healthy self-image (Hertnon 2005).

The mentioned challenges often prohibit children and youth from actively participating on the one hand and influence their emotional and spiritual well-being in that they are exposed to peer pressures and a deviation from spiritual growth on the other hand. Concluding from the discussion in this subsection, we considered that activities have to be aimed at developing relationships based on Christian values of respect, love and care for others. These relationships could assist children and youth to develop a healthy sense of morality and a Christian identity. In line with our viewpoint, Thomas and Benson (2010) reflected on the concepts of belonging, mastery, independence and generosity within the Circle of Courage model for youth empowerment and explains that because the current-day challenges experienced by youth, many have 'broken circles'. The following are examples of this brokenness:

- A sense of belonging is jeopardised by 'fractured families, unfriendly schools, and rejecting peers' that lead to a feeling of alienation with serious emotional and moral effects.

- Mastery becomes difficult in systems where youths are being judged as either winners or losers. Once categorised as a loser, a youth will stop pursuing his or her potential.

- Independence cannot be pursued when there is a lack of access to educational, spiritual, employment and social opportunities.

- Survival needs, together with growing up in a world where success is measured by wealth, leads to the fact that generosity in the form of care and contributions to others become less prioritised (Thomas \& Benson 2010:237-238).

Using the descriptions of faith-based concerns discussed in this subsection, the marginalisation of youths and the 'broken circle' above, we now continue to look at an innovative option to work towards demarginalisation in the next section.

\section{Towards demarginalisation}

Globally, youth are organising and mobilising groups to 'demand attention to issues that specifically affect them' (Columbia Global Policy Initiative 2014:6). In South Africa, the struggles of young people and students have shifted from activism against colonial racism, towards activism against marginalisation in a post-colonial, neo-liberal context (Nel 2015:518). Nel (2015:518) believes that the notion of 'youth marginalisation' was socially constructed within a broader framework of vilifying youth agency in the 1990s in South African media and it has become a key theme in youth research since the 1990s. This new activism against marginalisation could be framed as a growing discontent in a specific post-colonial context, but more importantly, as a sign of agency amongst youth and student movements. The most recent proliferation of student activism around the issues of transformation at universities in South Africa, organised around symbols on campuses, is a case in point (Nel 2015:518).

With a focus on faith-based concerns regarding the demarginalisation of youths, and in an effort to empower this group through a set of faith-based and contextually relevant principles, we propose the four key focus areas of the Circle of Courage, namely belonging, mastery, independence and generosity. These areas can serve as a guide when developing practices that are aimed at demarginalisation through a sense of betterment (cf. Hertnon 2005). We will firstly discuss the Circle of Courage as a model and then suggest how this model can integrate the Ubuntu principles.

\section{Circle of courage}

The Circle of Courage is a model for child and youth care work that is based on a study by Martin Brokenleg, a professor of Native American Studies, and Larry Brendtro, a professor in children's behaviour, on how indigenous cultures managed to raise children who became respectful and responsible young people without coercive ways of discipline. Based on their findings, they, together with Steve Von Bockern, developed the model in terms of a wheel that portrays four growth needs of all children and youth, namely belonging, mastery, independence and generosity. This model was also adopted for child and youth care services in South Africa during the early 2000s (Samjee 2010).

The Circle of Courage is aimed at supporting youth (and children) to develop into contributing members of society (Brendtro et al. 2002). When we searched for a possible way to demarginalise youth, based on the above description by Thomas and Benson (2010) of the broken circle experienced by South African Youth, we identified the Circle of Courage as a model of positive youth development. Principles underlying the Circle of Courage that relate to the demarginalisation of youth include the following:

- Youth are courageous and able to grow and develop.

- Youth should be motivated and encouraged. 


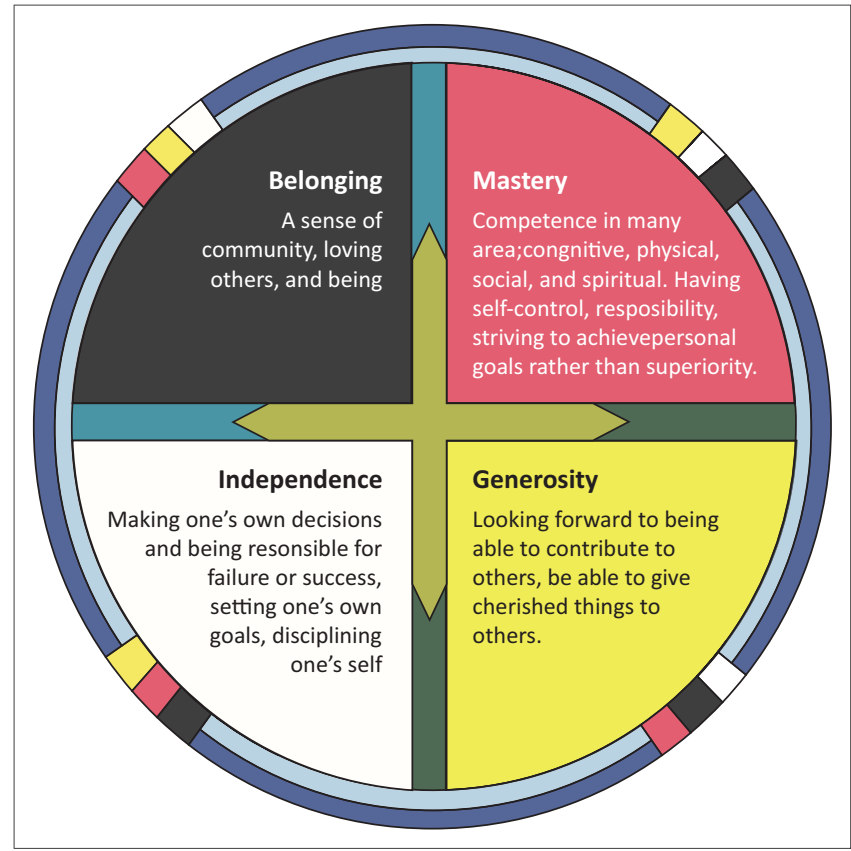

Source: Brendtro, L.K., Brokenleg, M. \& Von Bockern, S., 2002, Reclaiming youth at risk. Ou hope for the future, Rev. edn., Jossey-Bass, San Francisco, CA

FIGURE 2: Universal growth needs according to the Circle of Courage.

- When building resilience amongst youth, they are able to overcome challenges that affect their developmental process (Brendtro et al. 2002).

Therefore, interventions should focus on the development of the youth's self-worth. According to this model, there are four foundations for self-worth, namely:

- Significance ('I matter').

- Competence ('I can’).

- Power ('I can decide').

- Virtue ('I contribute').

These four foundations for self-worth are based on the mentioned four universal growth needs (Figure 2) of all children and youth (Samjee 2010).

Each of these growth needs as indicated in Figure 2 is connected to the other needs, meaning that what happens in one growth area will influence the other areas of the young person's life (Samjee 2010). In the discussion that follows, we will link the description of each growth need (Brend tro et al. 2002; Samjee 2010) with faith-based concerns regarding marginalised youth and also with focus areas for demarginalisation.

\section{The spirit of belonging}

The universal longing for human bonds is cultivated by relationships of trust so that a young person can say, 'I am loved'. Here the focus is on developing and nurturing communities of belonging for youths. Within congregational contexts and/or through services by FBOs, interactions and social experiences can serve as forces that contribute to youth development.

\section{The spirit of mastery}

The inborn thirst for learning is cultivated; by learning to cope with the world, young people can say, 'I can succeed'. This can take place in contexts where social observation assists youths to master developmental tasks. The ability to solve problems, find solutions and develop skills are nurtured to ensure a feeling of 'I can do this'.

\section{The spirit of independence}

Free will is cultivated by responsibility so that young people can say, 'I have the power to make decisions'. The focus is to build respect and teach inner discipline. Youths are encouraged to make decisions, solve problems and show personal responsibility. Within congregations and during service delivery by FBOs, services are aimed at nurturing (physical and emotional care), teaching values and giving feedback, whilst youths are given abundant opportunities to make choices without coercion.

\section{The spirit of generosity}

Character is cultivated by a concern for others so that young people can say, 'I have a purpose for my life'. This is linked to moral development where youths are guided towards understanding the importance of being generous and unselfish. In helping others, youths create their own proof of worthiness: They make a positive contribution to another human life.

The Circle of Courage can serve as a guideline for social and emotional care of youths in order to encourage demarginalisation through the development of internal motivation and strengths. Five interrelated sets of cognitive, affective and behavioural competencies are needed to provide the youth with social and emotional care (INEE 2016:8-9). Table 2 supports our suggestion of faith-based services that focus on these competencies aimed at demarginalising youths through a social space where emotional care, cognitive stimulation and an awareness of purpose can be cultivated.

Based on the above description of competencies that could be addressed through services by churches and other FBOs in an effort to provide social and emotional care, we will link the mentioned competencies to the four universal growth needs according to the Circle of Courage (cf. Brendtro et al. 2002), namely:

- Belonging: This principle relates well to Ubuntu ('I am because of $\mathrm{you}^{\prime}$, - in the spirit of the African people, who understand how important community, family, friendship, and sharing are). When working with young people, attempts to facilitate them to become part of a group are essential. For a sense of belonging to develop, activities for mastering should be aimed at:

- Respecting others and themselves.

- Building friendly relationships.

- Caring for others.

- Cooperating with others.

- Being trustworthy. 
TABLE 2: Cognitive, affective, and behavioural competencies for social and emotional care.

\begin{tabular}{|c|c|c|}
\hline Competency & Description & Relation to Circle of Courage \\
\hline Self-awareness & $\begin{array}{l}\text { The ability to accurately recognise one's emotions and thoughts and the influence on behaviour. This } \\
\text { includes accurately assessing one's own strengths and limitations and having a well-grounded sense of } \\
\text { confidence and optimism. }\end{array}$ & Mastery - 'I can succeed'. \\
\hline Self-management & $\begin{array}{l}\text { The ability to regulate one's emotions, thoughts and behaviours effectively in different situations. This } \\
\text { includes managing stress, controlling impulses, being self-motivating, setting personal and academic } \\
\text { goals and working to achieve them. }\end{array}$ & $\begin{array}{l}\text { Independence - 'I have the power to make } \\
\text { decisions'. }\end{array}$ \\
\hline Social awareness & $\begin{array}{l}\text { The ability to empathise with and understand the perspective of others from diverse backgrounds and } \\
\text { cultures. This includes understanding social and ethical norms of behaviour and recognising family, school } \\
\text { and community resources and supports. }\end{array}$ & $\begin{array}{l}\text { Belonging - 'I am loved'. } \\
\text { Generosity - 'I have a } \\
\text { purpose for my life'. }\end{array}$ \\
\hline Relational skills & $\begin{array}{l}\text { The ability to establish and maintain healthy and rewarding relationships with diverse individuals and } \\
\text { groups. This includes communicating clearly, listening actively, cooperating, resisting inappropriate social } \\
\text { pressure, negotiating conflict constructively, and seeking and offering help when needed. }\end{array}$ & $\begin{array}{l}\text { Belonging - 'I am loved'. } \\
\text { Generosity - 'I have a purpose for my life'. }\end{array}$ \\
\hline $\begin{array}{l}\text { Responsible } \\
\text { decision-making }\end{array}$ & $\begin{array}{l}\text { The ability to make constructive and respectful choices about personal behaviour and social interactions. } \\
\text { These choices are based on a consideration of ethical standards, safety concerns, social norms, the } \\
\text { realistic evaluation of consequences of various actions and the well-being of self and others. }\end{array}$ & $\begin{array}{l}\text { Mastery - 'I can succeed'. } \\
\text { Independence - 'I have the power to } \\
\text { make decisions'. } \\
\text { Generosity - 'I have a purpose for my life'. }\end{array}$ \\
\hline
\end{tabular}

Source: Inter-Agency Network for Education in Emergencies (INEE), 2016, Psychosocial support and social and emotional learning for children and youth in emergency settings, INNE, New York

- Mastery: Humans have an innate drive to become competent and solve problems. Through providing youths with opportunities to experience success in overcoming challenges, the desire to achieve is strengthened. We propose that the following abilities be encouraged, modelled and taught:

- Creativity (problem-solving, expression through music or art, etc.).

- Persistence (keep on trying).

- Accepting challenges (finding ways to deal with situations).

These capabilities lead to the ability to accept and deal with life situations.

- Independence: Independence assists young people to make decisions, solve problems, and show personal responsibility. Adults model, nurture and teach values, and give feedback, but youths should be given plenty of opportunities to make choices without pressure. Independence is needed to become able to take responsibility for oneself and for others. Youths need assistance and guidance regarding particular life skills to be able to learn to function independently. Such life skills include the following:

- Assertiveness.

- Confidence.

- Leadership skills.

- Problem-solving skills.

- Self-control.

- Discipline (to finish a task, to persevere).

- Generosity: In helping others, youths create proof of worthiness by making a positive contribution to another human life. A person who has a sense of belonging, who experienced mastery and who is able to function independently is also able to become generous. This means that he or she is able to contribute positively to others and to society in general. In order for youths to become generous, activities should focus on the following abilities:

- Sharing.

- Caring.

- Supporting.

- Helping.

- Showing concern and compassion.
In order to contextualise the application of the Circle of Courage to demarginalise youths, we are suggesting that the principles of Ubuntu become part of a lived experience within FBO and congregational settings.

\section{Principles of Ubuntu}

Thumbadoo (2013) quotes Desmond Tutu when explaining the concept of UBUNTU within the African (including South African) context:

UBUNTU has to do with human nature. It refers to the essence of being an African, it offers us an understanding of ourselves in relation with the world: There is a common bond between all people and through this bond and our interaction with others we discover our own human qualities, and this awareness of humanity is a way in which African people make a contribution to the world. (p. 17)

UBUNTU represents a viewpoint that we are interdependent on each other - we 'are' through other people. It means that if a person respects or disrespects another person, he or she automatically also respects or disrespects himself or herself. It also means that we work together for the common good. If you view yourself as independent from others, you cannot share in the common good. The principles that underpin the spirit of UBUNTU refer to:

- Hospitality.

- Caring about others.

- Being able to go the extra mile for the sake of others (Thumbadoo 2013:70).

The Circle of Courage provides us with a framework where the humanness of youths can be nourished. Another way of expressing humanness is through the African concept of Ubuntu. According to Kgatla (2016:71), Ubuntu is the spirit of common good for all and is based on God's love, signifying the very nature of a God who exists for the sake and wellbeing of humans. He (Kgatla) further states that those who are imbued with God's love are said to possess the quality of Ubuntu that seeks to empower and transform those who are socially dehumanised and rejected purely because of their material and social conditions (Kgatla 2016:71). Ubuntu underscores solidarity and relationality by and between all 
TABLE 3: Implementing the principles of Ubuntu as part of the Circle of Courage.

\begin{tabular}{ll}
\hline $\begin{array}{l}\text { Elements of the Circle } \\
\text { of Courage }\end{array}$ & $\begin{array}{l}\text { Example of how it is implemented } \\
\text { in Ubuntu }\end{array}$ \\
\hline Spirit of belonging & $\begin{array}{l}\text { Youths learn from each other (peer groups) and from } \\
\text { adults about the value of interdependence and } \\
\text { community. Belonging then does not only refer to blood } \\
\text { relations but also to groups and communities where } \\
\text { physical, emotional, social, cognitive and spiritual needs } \\
\text { are met. }\end{array}$ \\
Spirit of mastery & $\begin{array}{l}\text { Achieving competence has to be seen in a holistic light, } \\
\text { not just with respect to work-related talents but also } \\
\text { with respect to character formation. Youth learn mastery } \\
\text { through games, and adults reinforce the notion that } \\
\text { striving is prised over rivalry or display of arrogance } \\
\text { (by the winner or winning team). }\end{array}$ \\
Spirit of independence & $\begin{array}{l}\text { Personal autonomy and responsibility are valued in } \\
\text { communities. Young people receive advice and modelling } \\
\text { from adults who show them how to become } \\
\text { independent. However, young people are allowed to } \\
\text { struggle to find solutions and to work out how to deal } \\
\text { with problems. }\end{array}$ \\
& $\begin{array}{l}\text { Activities of community work (e.g. rendering services to } \\
\text { the elderly in the community) model to young people } \\
\text { how to contribute to the needs of others. Youths are } \\
\text { steered away from self-centred, self-destructive or } \\
\text { anti-social attitudes and towards the peace-making } \\
\text { ideal that they matter because they make a difference } \\
\text { in others' lives. }\end{array}$ \\
\hline
\end{tabular}

individuals and requires them to live, on a daily basis, for the wellness of the whole community without exception. Relationality, mutuality, reciprocity and interdependence are features without which Ubuntu cannot take root in the community. Within this description, we argue that the principle of Ubuntu relates well to the practice of the Circle of Courage. It also requires that faith-based actions towards the demarginalisation of youths should be based on these principles, whilst teaching young people the value thereof. The Circle of Courage serves as a practical manner in which such efforts can function according to the principles of Ubuntu (Nagel 2008:11-16), as we illustrate in Table 3.

We identified the Circle of Courage, together with the principles of Ubuntu, as a strategy to empower youths within the context of faith-based contributions to the demarginalisation of youths. We are concluding our discussion with a practical suggestion for the characteristics of the outcomes of such a strategy.

\section{Practical guidelines for action by churches and faith-based organisations}

Various authors suggest that youth ministries should be based on the lived experiences and contextual challenges and needs of young people as a distinctive marginalised group (cf. Beukes \& Van der Westhuizen 2016:24-25; Cloete 2012:70, 2015:4; Knoetze 2015:3). In our own discussion, we went a step further by saying that both children and youths should be included in such efforts towards demarginalisation. Our viewpoint is that, when children are being supported with a sense of belonging and mastery, they will be able to move towards independence and generosity as young people.

We conclude this article by providing more pertinent guidelines for the outcomes of faith-based activities directed to youths, according to the Circle of Courage and principles of Ubuntu.
The first guideline is that the outcome should be reciprocal in nature. The youths learn from each other, share ideas, responsibilities and successes and complement each other. Through these activities, the Ubuntu principles of being cared for, caring about others and going an extra mile for the sake of others are being practiced. The focus is on the spirit of belonging.

Secondly, activities should be purposeful and structured so that the youths can master skills and address developmental needs with the guidance and support of adults. In this way, they feel cared for and valued and experience the spirit of mastery in a safe, caring and respectful environment.

A third guideline is that youths must experience support and give support. They learn to express feelings without a fear of being judged or labelled and can support each other to achieve behavioural changes and to experience success. In this way, Ubuntu is experienced through being cared for, caring about others and viewing the world in terms of 'my humanity is bound up in yours'. This should lead to experiences related to the spirits of belonging, mastering and independence.

Lastly, faith-based efforts towards the demarginalisation of youth should be collective in nature. Change should happen in the life spaces of young people so that they can come into positive contact with the community they live in. For example, by cleaning up the neighbourhood and selling their own work, the community learns about the virtues of such young people. Such collective activities create opportunities to experience the spirit of belonging, mastering and generosity.

\section{Conclusion}

In this article we recommended that efforts to empower young people should not be located in 'once-off' projects, but rather become part of a congregational culture and of faithbased activities where a sense of belonging leads to selfworth that encourages the mastering of skills needed to solve problems and finding solutions for improving one's own circumstances and those of others as well. However, the mere mastering of skills is not enough. Youths should be supported to move towards independence, whilst experiencing a feeling of belonging and creating more opportunities to experience mastery.

Finally, the practical guidelines proposed in this article should create a space where youths become aware of their value to larger society, which should result in generosity and the ability to show acts of kindness. We argue that, when the growth needs of both children and youths are being addressed, whilst also including the principles of Ubuntu, opportunities are being developed that are in line with the National Youth Policy's focus areas for FBO support to demarginalise youths (cf. Republic of South Africa 2015:25-26). We conclude that, through the 
implementation of the presented practical guidelines, FBOs can create safe spaces for youths where they can show love, respect and care to themselves and others. In such a space, they can learn about honesty, social justice and work ethics. Through such learning experiences, they can be led towards the development of skills to achieve their potential so that they can actively contribute to the socio-economic development of their contexts. In this way, the implementation of our guidelines may result in relational interactions underscored by solidarity in which Ubuntu should come alive in African ways of life. These African ways of life manifest in principles of Ubuntu where youths live in a community where a culture of 'being because of each other' will direct their development. In this culture of humanity, they are provided with a feeling that they belong, can master skills and become independent and are able to care about each other.

\section{Acknowledgements Competing interests}

The authors declare that they had no financial or personal relationships which may have inappropriately influenced them in writing this article.

\section{Authors' contributions}

J.B and M.v.d.W. conducted the research that informed this study. The theoretical framework and presentation of this article resulted from a collaborative effort by both J.B and M.v.d.W.

\section{References}

Beukes, J.W. \& Van der Westhuizen, M., 2016, 'Exploring the voices of children and youth: A plea for renewal in Church structures for child and youth ministries', Stellenbosch Theological Journal (STJ) 2(2), 111-130.

Brendtro, L.K., Brokenleg, M. \& Von Bockern, S., 2002, Reclaiming youth at risk. Our hope for the future, Rev. edn., Jossey-Bass, San Francisco, CA.

Bowers du Toit, N.F., 2017, 'Meeting the challenge of poverty and inequality? 'Hindrances and helps' with regard to congregational mobilisation in South Africa', HTS Theological Studies 73(2), a3836. https://doi.org/10.4102/hts.v73i2.3836

Calitz, C.J., 2017, 'Healing liturgy: The role of music and singing', Verbum et Ecclesia 38(1), a1628. https://doi.org/10.4102/ve.v38i1.1628

Clarke, G., 2006, 'Faith matters: Faith-based organisations, civil society and international development', Journal of International Development 18, 835-848. https://doi.org/10.1002/jid.1317

Cloete, A., 2012, 'Spiritual formation as focus of youth ministry', Dutch Reformed Theological Journal 53(3-4), 70-77.

Cloete, A., 2015, 'Creative tensions in youth ministry in a congregational context', HTS Theological Studies 71(2), 1-7. https://doi.org/10.4102/hts.v71i2.2107

Columbia Global Policy Initiative, 2014, Overcoming youth marginalization conference report and policy recommendations, Conference in March 2014. Columbia Global Policy Initiative and the Office of the United Nations Secretary-General's Envoy on Youth, New York.

Department of Higher Education and Training, 2017, Fact Sheet on 'NEETS' (Persons who are Not in Employment, Education or Training), viewed 15 March 2017, from http://www.dhet.gov.za/Planning\%20Monitoring\%20and\%20Evaluation $\% 20$ Coordination/Fact-sheet-on-NEETs-Final-Version-27-Jan-2017.pd

Department of Social Development, 2013, Framework for social welfare services, Department of Social Development, Pretoria.

Fagan, J., Sulzbacher, S., Karkara, R., Castilho, L. \& Bah, C., 2014, A rights-based approach to youth inequalities, Conference on 'Overcoming youth marginalization conference report and policy recommendations' in March 2014. Columbia Global Policy Initiative and the Office of the United Nations Secretary-General's Envoy on Youth, New York.

Firet, J., 1977, Het agogisch moment in het pastoraal optreden, Kampen, Kok.

Firet, J., 1986, Dynamics in pasturing, transl. J. Vriend, Eerdmans, Grand Rapids, MI.
Flint, J., Atkinson, R. \& Kearns, A., 2002, Churches and social capital: The role of Church of Scotland congregations in local community development, The Church of Scotland Board of Social Responsibility, Glasgow.

Furlong, A., Morsy, H., Deshingkar, P. \& Younis, L., 2014, Youth experiences of employment, education and migration, Conference on 'Overcoming youth marginalization conference report and policy recommendations' in March 2014 Columbia Global Policy Initiative and the Office of the United Nations SecretaryGeneral's Envoy on Youth, New York.

Hertnon, S., 2005, Theory of universal human needs, viewed 24 November 2012, from http://www.nakedize.com/universal-human-needs.cfm\#article

Inter-Agency Network for Education in Emergencies (INEE), 2016, Psychosocial support and social and emotional learning for children and youth in emergency settings, INNE, New York.

Kgatla, S.T., 2016, 'Relationships are building blocks to social justice: Cases of biblical justice and African Ubuntu', HTS Theological Studies 72(1), 70-76. https://doi. org/10.4102/hts.v72i1.3239

Knoetze, J., 2015, 'Perspectives on family and youth ministry embedded in the missio Dei - an African perspective', Skriflig 49(1), 1-9. https://doi.org/10.4102/ids. v49i1.1874

Knoetze, J.J., 2017, 'Who are the disciples? Identity perceptions about millennials and the church', Verbum et Ecclesia 38(1), a1718. https://doi.org/10.4102/ve.v38i1.1718

Kousiakis, S.A., 2015, 'Creating sustainable lives. A case study of youth in South Africa', Unpublished MPhil Thesis, University of Oslo.

Laiq, N., Alkali, A., Sheinberg, D., George, S. \& Lee, C., 2014, Youth in governance and political participation, Conference on 'Overcoming youth marginalization conference report and policy recommendations' in March 2014, Columbia Global Policy Initiative and the Office of the United Nations Secretary-General's Envoy on Youth, New York.

Louw, D. \& Louw, A., 2007, Child and adolescent development, University of the Free State, Bloemfontein.

Mosavel, M., Ahmed, R., Ports, K.A. \& Simon, C., 2013, 'South African, urban youth narratives: Resilience within community', International Journal of Adolescence and Youth 20(2), 245-255. https://doi.org/10.1080/02673843.2013.785439

Nagel, M., 2008, Promises of Ubuntu in the New South Africa, Cortland, New York.

National Planning Commission, 2012, National Development Plan: 2030, Government Printers, Pretoria.

Nel, M., 2009, 'Congregational analysis: A theological and ministerial approach', HTS Theological Studies 65(1), 1-17, viewed 21 January 2018, from http://www.scielo. org.za/scielo.php

Nel, M.H., 2001, 'The inclusive congregational approach to youth ministry', in M.H Senter III (ed.), Four views of youth ministry and the church, Zondervan Publishing House, Grand Rapids, MI.

Nel, R., 2015, 'Social media and the new struggles of young people against marginalisation: A challenge to missional ecclesiology in Southern Africa', Stellenbosch Theological Journal (STJ) 1(2), 511-530. https://doi.org/10.17570/ stj.2015.v1n2.a24

Pieterse, D., 2015, 'Childhood maltreatment and educational outcomes: Evidence from South Africa', Health Economics 24(7), 876-894. https://doi.org/10.1002/ hec.3065

Rankin, N., Roberts, G. \& Schöer, V., 2012, The challenges that young South Africans face in accessing jobs: Could a targeted wage subsidy help?, African MicroEconomic Research Unit (AMERU), Johannesburg.

Republic of South Africa, 2015, National Youth Policy 2015-2020: The authors are generation 2020. The authors don't want a hand-out, the authors want a hand up!, The Presidency of the Republic of South Africa, Pretoria.

Samjee, S., 2000, 'The circle of courage', E-Journal of the International Child and Youth Care Network 15, np, viewed 04 April 2018, from http://www.cyc-net.org/cyconline/cycol-0400-circle.htm

Stanley, N., Miller, P. \& Foster, H.R., 2012, 'Engaging with children's and parents' perspectives on domestic violence', Child and Family Social Work 17(2), 192-201. https://doi.org/10.1111/j.1365-2206.2012.00832.x

Statistics South Africa, 2015, National and provincial labour market: Youth, StatsSA, Pretoria.

Statistics South Africa, 2017a, Poverty trends in South Africa: An examination of absolute poverty between 2006 and 2015, StatsSA, Pretoria.

Statistics South Africa, 2017b, Quarterly labour force survey, StatsSA, Pretoria.

Thomas, R.M. \& Benson, P.L., 2010, 'Review of all kids are our kids: What communities must do to raise caring and responsible children and adolescents, 2 nd edn., Clearing House', A Journal of Educational Strategies, Issues and Ideas 81(5), 237-238.

Thornton, V., 2014, 'Understanding the emotional impact of domestic violence on young children', Educational and Child Psychology 31(1), 90-100.

Thumbadoo, Z.S., 2013, 'Ways in which child and youth care workers support childheaded households in communities', Unpublished degree of Magister Technologiae in the subject Child and youth care, University of Pretoria, Pretoria.

Van der Westhuizen, M.A. \& Swart, I., 2015, 'The struggle against poverty, unemployment and social injustice in present-day South Africa: Exploring the involvement of the Dutch Reformed Church at congregational level', Stellenbosch Theology Journal (STJ) 1(2), 731-759. https://doi.org/10.17570/stj.2015.v1n2.a35

Warnick, D.V., 2017, 'Experiencing domestic violence as a child: Young adults' recollections and suggestions for social work services', Unpublished thesis for a Master's Degree in Social Work, University of South Africa, Pretoria.

World Economic Forum, 2014, Global risks report, WEF, Geneva. 